OPEN ACCESS

Edited by:

Pietro Speziale,

Istituto Universitario Di Studi Superior

Di Pavia, Italy

Reviewed by:

Fabio Bagnoli,

GlaxoSmithKline, Italy

John Yu-Shen Chen,

National University of Singapore,

Singapore

*Correspondence:

Gérard Lina

gerard.lina@univ-lyon1.fr

Received: 12 August 2016 Accepted: 24 November 2016 Published: 12 December 2016

Citation:

Hodille E, Cuerq C, Badiou C, Bienvenu F, Steghens J-P, Cartier R, Bes M, Tristan A, Plesa A, Le VTM. Diep BA, Lina G and Dumitrescu O

(2016) Delta Hemolysin and

Phenol-Soluble Modulins, but Not Alpha Hemolysin or Panton-Valentine Leukocidin, Induce

Mast Cell Activation.

Front. Cell. Infect. Microbiol. 6:180. doi: 10.3389/fcimb.2016.00180

\section{Delta Hemolysin and Phenol-Soluble Modulins, but Not Alpha Hemolysin or Panton-Valentine Leukocidin, Induce Mast Cell Activation}

\author{
Elisabeth Hodille ${ }^{1,2}$, Charlotte Cuerq ${ }^{2,3}$, Cédric Badiou ${ }^{1}$, Françoise Bienvenu ${ }^{2,4}$ \\ Jean-Paul Steghens ${ }^{2,3}$, Régine Cartier 2,5, Michèle Bes ${ }^{1,2,6}$, Anne Tristan 1, 2,6, \\ Adriana Plesa ${ }^{2,7}$, Vien T. M. Le ${ }^{8}$, Binh A. Diep ${ }^{8}$, Gérard Lina ${ }^{1,2,6 *}$ and Oana Dumitrescu ${ }^{1,2,6}$ \\ ${ }^{1}$ Centre International de Recherche en Infectiologie, Institut National de la Santé et de la Recherche Médicale U1111, \\ Université Lyon 1, Centre National de la Recherche Scientifique UMR5308, Ecole Normale Supérieure de Lyon, Lyon, France, \\ ${ }^{2}$ Hospices Civils de Lyon, Lyon, France, ${ }^{3}$ Laboratoire de Biochimie, Centre de Biologie Sud, Lyon, France, ${ }^{4}$ Laboratoire \\ d'Immunologie, Centre de Biologie Sud, Lyon, France, ${ }^{5}$ Laboratoire de Biochimie, Groupement Hospitalier Est, Lyon, France, \\ ${ }^{6}$ Centre National de Référence des Staphylocoques, Bron, France, ${ }^{7}$ Laboratoire d'hématologie, Centre de Biologie Sud, \\ Lyon, France, ${ }^{8}$ Division of HIV, Infectious Diseases and Global Medicine, Department of Medicine, University of California, \\ San Francisco, CA, USA
}

Mast cells are located at host interfaces, such as the skin, and contribute to the first-line defense against pathogens by releasing soluble mediators, including those that induce itching and scratching behavior. Here, we show that delta-hemolysin (HId) and phenol soluble modulins (PSMs) PSM 1 and PSM $\alpha 3$, but not alpha-hemolysin (Hla) or Panton-Valentine leukocidin (PVL), induce dose-dependent tryptase, and lactate dehydrogenase $(\mathrm{LDH})$ release by the $\mathrm{HMC}-1$ human mast cell line. Using supernatants from isogenic strains, we verified that tryptase and $\mathrm{LDH}$ release was HId- and PSM $\alpha$-dependent. PSM $\alpha 1$ and Hld production was detected in 65 and $17 \%$ of human Staphylococcus aureus-infected skin abscess specimens, respectively, but they were produced in vitro by all clinical isolates. The results suggest that HId and PSM- $\alpha 1$ produced in vivo during $S$. aureus skin infections induce the release of mast cell mediators responsible for itching and scratching behavior, which may enhance skin to skin transmission of S. aureus via the hands. As HId and PSMs are upregulated by accessory gene regulator (agr), their association may contribute to the elective transmission of $S$. aureus strains with a functional agr system.

\begin{abstract}
Keywords: Staphylococcus aureus, mast cells, phenol-soluble modulins, delta hemolysin, virulence, accessory
\end{abstract} gene regulator, hand-transmission

\section{INTRODUCTION}

Microorganisms are increasingly being recognized to have profound effects on the host they invade (Shropshire and Bordenstein, 2016). In many cases, host behaviors are altered upon infection by diverse pathogens, including bacteria (Cameron and Sperandio, 2015). These observed changes in host behavior are often thought to be beneficial to the microorganisms, as they may increase the rate of transmission (Cézilly and Perrot-Minnot, 2005). 
Staphylococcus aureus is both a commensal and extremely versatile pathogen and one of the most common causes of bacterial community and healthcare-associated infections in humans (Lowy, 1998). S. aureus primarily causes skin and soft tissue infections (SSTIs), bloodstream infections, and pneumonia. The pathogenicity of S. aureus is determined by the extended repertoire of toxins produced by this bacteria (Kong et al., 2016). In vitro and in vivo studies in animals have identified pore-forming toxins, such as Panton-Valentine leukocidin (PVL), alpha-hemolysin (Hla), phenol-soluble modulin-alpha (PSM $\alpha$ ), and delta-hemolysin (Hld), as major virulence factors involved in the pathophysiology of staphylococcal skin infections (Wang et al., 2007; Kobayashi et al., 2011; Lipinska et al., 2011; Syed et al., 2015). These toxins are capable of targeting a wide variety of immune cells during infection, such as human polymorphonuclear leukocytes, monocytes, and macrophages, and can significantly contribute to dampening both innate and adaptive immune response to $S$. aureus infection (Pozzi et al., 2015).

The expression of PVL, Hla, and PSMs is regulated in different manners by accessory gene regulator (agr), a quorum sensing system in S. aureus. Hld is encoded by RNAIII, a non-coding RNA that orchestrates the expression of most virulence factors (Novick et al., 1993), including PVL and Hla (Vandenesch et al., 1991; Dumitrescu et al., 2011). In contrast, PSM $\alpha$ expression is regulated by AgrA, the response regulator of the two component system that activates the agr system (Lina et al., 1998; Queck et al., 2008).

Skin to skin contact via the hands plays a significant role in the spread of S. aureus to new hosts not only in hospitals, but also in nursing homes and child care settings, among others (Bloomfield and Scott, 1997). Increasing the frequency of contact between one's hand and skin colonized or infected by $S$. aureus due to itching and scratching behavior may enhance the transmission potential of the pathogen. The induction of scratching behavior in animals during experimental skin infection by $S$. aureus was described a long time ago (Wagner et al., 1997) but only recently described in humans when skin infections induced by community-acquired methicillin-resistant $S$. aureus (CAMRSA) were misidentified by both patients and physicians as spider bites because they were very erythematous, indurated, and itchy, sometimes with a central dermo-necrosis (Suchard, 2011).

The skin is considered a major interface of the body for the host defense, not only as a passive barrier, but also through the immune system. Innate immune cells residing in the skin, such as Langerhans cells, dendritic cells, and dermal mast cells, provide cutaneous immune surveillance (Kupper and Fuhlbrigge, 2014). Mast cells are leukocytes originating from hematopoietic progenitor cells and located at host interfaces with the environment, such as the skin, pulmonary, and digestive mucosa. Mast cell differentiation and maturation are different according to the organs in which they are located. Two major phenotypes of mature mast cells are differentiated by granule content and the receptors expressed: Phenotype T contains mainly tryptase, and phenotype TC contains mainly tryptase and chymase (Galli et al., 2011).
These cells are able to recognize pathogenic agents and trigger the inflammatory process through complex inter-cellular communication mediated by several mediators released by mast cells. Thus, mast cells participate in the first line of defense in innate immunity against pathogens, including bacteria (Abraham and St. John, 2010).

Mast cells express several receptors capable of recognizing pathogens that belong to pattern recognition receptor (PRR) family involved in the recognition of pathogen-associated molecular patterns (PAMPs), such as Toll-like receptors (TLRs) TLR1 to TLR9, Nod-like receptors (NLRs), and C-type lectin receptors (CLRs), including dectin-1 (Urb and Sheppard, 2012; St. John and Abraham, 2013). Pathogen recognition induces several activation pathways in mast cells, resulting in the release of mediators, such as intra-cytoplasmic granules (histamine, protease, tryptase, tumor necrosis factor [TNF]), lipid-derived eicosanoids (leukotrienes and prostaglandins), and cytokines or chemokines, including TNF, IL-4, and IL-6 (Abraham and St. John, 2010; Urb and Sheppard, 2012; St. John and Abraham, 2013). After bacterial invasion, mast cells preferentially release IL-8 and TNF to promote polymorphonuclear neutrophil (PMN) recruitment at the infection site (Urb and Sheppard, 2012). First, TNF, IL-6, and IL-8 promote PMN chemotaxis. Next, TNF and eicosanoid trigger an up-regulation of adhesion molecules on the endothelial cell surface and vascular permeability, allowing PMN adhesion to endothelial cells and diapedesis (Abraham and St. John, 2010). In addition, mast cells can directly kill pathogens via the production of antimicrobial peptides known as cathelicidins (Di Nardo et al., 2003).

Mast cells can recognize bacteria through TLR-2 and TLR4, which recognize the lipopolysaccharides of Gram-negative bacteria and peptidoglycans of Gram-positive bacteria, and through TLR-5, which recognizes flagellin (Abraham and St. John, 2010). Mast cell mediators are also known to activate neuroreceptors on sensory nerve fibers involved in the induction of pruritus (Ständer et al., 2008).

Only a few studies have examined the interaction between S. aureus and mast cells. S. aureus induces mast cell activation through peptidoglycan-sensing by TLR2 (Feng et al., 2007). Two recent studies also confirmed that $S$. aureus-exposed mast cells release pro-inflammatory cytokines, such as IL-8, IL-3, IL-13, and TNF- $\alpha$ (Rönnberg et al., 2014; Swindle et al., 2015). Furthermore, $S$. aureus internalization by mast cells is enhanced by Hla and induces the release of extracellular traps, antimicrobial compounds, and pro-inflammatory cytokines (Abel et al., 2011; Goldmann et al., 2016; Johnzon et al., 2016). Nakamura et al. (2013) also demonstrated in a mouse model that S. aureus Hld induces skin mast cell activation, promoting the establishment of atopic dermatitis, an allergic skin disease. However, no data are yet available on the effect of other staphylococcal toxins involved in skin pathophysiology on human mast cells.

The aim of our study was to investigate whether $S$. aureus produces virulence factors during skin infection that may increase the rate of transmission by stimulating itching and scratching behavior through mast cell activation. We examined the impact of virulence factors involved in skin infection pathophysiology on skin mast cell activation and verified 
there in vivo production in human $S$. aureus skin abscess samples.

\section{MATERIALS AND METHODS Staphylococcal Virulence Factors and Cells}

The staphylococcal virulence factors used in this study were PVL, Hla, Hld, PSM $\alpha 1$, and PSM $\alpha 3$. The recombinant proteins LukSPVL, LukF-PVL, and Hla were produced in our laboratory and resuspended in phosphate buffered saline (PBS) as described previously (Perret et al., 2012). Recombinant PVL activity on the plasma membranes of human polymorphonuclear leukocytes (PMNs) was verified on human PMNs before the study (Supplementary Figure 1). Briefly, purified LukS-PV and LukFPV were diluted in RPMI to equimolar concentrations (0.05$0.5 \mu \mathrm{g} / \mathrm{mL}$, i.e., $0.0015-0.015 \mu \mathrm{M})$ and mixed with human PMNs $\left(10^{6}\right.$ cells) in the presence of $500 \mathrm{ng}$ propidium iodide (PI). The percentage of PI-positive PMNs was determined by flow cytometry (Becton Dickinson Accuri C6 Flow Cytometer) at 5, $10,15,20,25$, and $30 \mathrm{~min}$.

The activities of alpha-hemolysin preparations were also confirmed by cell permeability assays using rabbit erythrocytes (Supplementary Figure 2). Recombinant Hla was diluted in PBS (0.001-10 $\mu \mathrm{g} / \mathrm{mL}$, i.e., $\left.3 \times 10^{-5}-0.3 \mu \mathrm{M}\right)$ and mixed at equal volume in a solution of $2 \%$ washed rabbit erythrocytes (bioMérieux). After $60 \mathrm{~min}$ of incubation at $37^{\circ} \mathrm{C}$, samples were centrifuged at $200 \times \mathrm{g}$ for $5 \mathrm{~min}$ and the $\mathrm{OD}_{405 \mathrm{~nm}}$ of the supernatants measured. The percentage hemolysis of each sample was compared to that of erythrocytes lysed with $1 \%$ Triton-X.

$P S M \alpha 1, P S M \alpha 3$, and Hld were synthesized in the $\mathrm{N}$ formylated form by Genecust Europe ${ }^{\circledR}$ (Luxembourg) with a purity greater than $90 \%$ and resuspended in PBS before their use. The HMC-1 human mast cell line was kindly provided by Olivier Lortholary (Pasteur Institute, Paris, France) and cultured in Iscove's modified Eagle's medium (IMDM) supplemented with $10 \%$ fetal calf serum (FCS) and $40 \mu \mathrm{g} / \mathrm{mL}$ gentamicin in $5 \% \mathrm{CO}_{2}$ at $37^{\circ} \mathrm{C}$. For cell experiments, HMC- 1 cell cultures were adjusted to $1 \times 10^{6}$ cells $/ \mathrm{mL}$ in IMDM without FCS.

\section{S. aureus Strains and Bacterial Culture}

Twenty-three $S$. aureus clinical strains isolated from SSTIs were provided by the French National Reference Center (NRC) for Staphylococci. For each strain, the agr group, MLST-clonal complex or sequence type (ST), mecA, Luk-PV gene, Hla, and Hld were detected using a $S$. aureus microarray genotyping kit (Alere, Jouy-en-Josas, France) as described previously (Monecke et al., 2009) (Table 1). Moreover, isogenic mutants of a $S$. aureus USA300-0114 clinical strain, SF8300, were constructed using the oligonucleotides in Supplemental Table S1 and the pKOR1 allelic replacement mutagenesis system as described previously (Bae and Schneewind, 2006; Diep et al., 2010). SF8300 $\Delta$ psm $\alpha 1-4$ and SF8300 $\Delta a g r A$ mutants contain in-frame deletions of genes encoding PSM-alpha types $\alpha 1-\alpha 4$ and AgrA. SF8300Hld $(3 \mathrm{G}>\mathrm{T})$ mutant contains a single nucleotide change that changes the start codon ATG to ATT to block the initiation
TABLE 1 | Epidemiological characteristics of $S$. aureus strains isolated from SSTIs.

\begin{tabular}{|c|c|c|c|c|}
\hline \multirow[t]{2}{*}{ S. aureus isolate } & \multicolumn{4}{|c|}{ Strain characteristics } \\
\hline & $\begin{array}{c}\text { agr } \\
\text { group }\end{array}$ & $\begin{array}{c}\text { MLST or } \\
\text { Clonal Complex }\end{array}$ & $\begin{array}{c}\text { mecA } \\
\text { detection }\end{array}$ & $\begin{array}{c}\text { luk-PV } \\
\text { detection }\end{array}$ \\
\hline ST 20120567 & 1 & 152 & - & + \\
\hline ST 20140236 & 1 & 398 & - & - \\
\hline ST 20111376 & 1 & 398 & - & - \\
\hline ST 20130774 & 1 & 398 & - & - \\
\hline ST 20081085 & 1 & 188 & - & + \\
\hline ST 20121286 & 1 & 188 & - & + \\
\hline ST 20131093 & 1 & 22 & - & + \\
\hline ST 20071243 & 3 & 30 & - & + \\
\hline$\underline{\text { ST } 20140589}$ & 1 & 8 & - & - \\
\hline$\underline{\text { ST } 20141539}$ & 1 & 45 & - & - \\
\hline ST 20131442 & 1 & 97 & - & - \\
\hline ST 20120823 & 1 & 22 & - & - \\
\hline ST 20121497 & 1 & 152 & - & + \\
\hline$\underline{\text { ST } 20140351}$ & 1 & 97 & - & - \\
\hline ST 20071031 & 3 & 80 & + & + \\
\hline ST 20111384 & 2 & 5 & + & - \\
\hline$\underline{\text { ST } 20151708}$ & 1 & 398 & - & - \\
\hline ST 20120341 & 3 & 80 & + & + \\
\hline ST 20070901 & 3 & 30 & - & + \\
\hline ST 20101173 & 1 & 8 & + & + \\
\hline ST 20102118 & 3 & 80 & + & + \\
\hline$\underline{0150331644}$ & 3 & 30 & - & - \\
\hline ST 20110395 & 2 & 5 & - & - \\
\hline ST 20131215 & 1 & 45 & - & - \\
\hline$\underline{\text { ST } 20141054}$ & 1 & 45 & - & - \\
\hline$\underline{\text { ST } 20151706}$ & 1 & 25 & - & - \\
\hline ST 20120150 & 1 & 45 & - & - \\
\hline ST 20091153 & 2 & 5 & - & - \\
\hline$\underline{\text { ST } 20141173}$ & 3 & 80 & + & + \\
\hline ST 20121322 & 3 & 80 & - & + \\
\hline$\underline{\text { ST } 20140441}$ & 3 & 30 & - & - \\
\hline HT 20041093 & 3 & 88 & - & + \\
\hline ST 20101734 & 2 & 15 & - & - \\
\hline ST 20141524 & 2 & 2482 & - & + \\
\hline$\underline{\text { ST } 20151705}$ & 3 & 30 & - & - \\
\hline ST 20131745 & 1 & 8 & - & - \\
\hline$\underline{\text { ST } 20141033}$ & 2 & 5 & + & - \\
\hline$\underline{\text { ST } 20140409}$ & 3 & 30 & - & + \\
\hline ST 20131301 & 2 & 15 & - & - \\
\hline$\underline{\text { ST } 20151710}$ & 3 & 30 & - & - \\
\hline ST 20110514 & 3 & 30 & - & - \\
\hline ST 20090867 & 1 & 8 & - & - \\
\hline ST 20151711 & 3 & 30 & - & - \\
\hline ST 20151707 & 2 & 5 & - & - \\
\hline$\underline{\text { ST } 20141501}$ & 3 & 30 & - & - \\
\hline$\underline{\text { ST } 20151709}$ & 2 & 5 & - & - \\
\hline
\end{tabular}

Underlined isolates correspond to clinical samples analyzed for toxin quantification. 
of its translation. Colonies of SF8300WT, SF8300 $\Delta$ psma1-4, and $\mathrm{SF} 8300 \mathrm{Hld}(3 \mathrm{G}>\mathrm{T})$ were hemolytic on blood agar plate suggesting that agr was functional in these mutants. AgrAknockout induces an alteration of the agr system and PSM $\alpha 1-$ 4 production (Peschel and Otto, 2013). S. aureus supernatants were prepared by growing bacteria adjusted to 0.5 MacFarland standard in $3 \mathrm{~mL}$ of CCY broth in a rotary shaker $(190 \mathrm{rpm})$ at $37^{\circ} \mathrm{C}$ for $22 \mathrm{~h}$, followed by centrifugation for $10 \mathrm{~min}$ at 3000 $\times \mathrm{g}$ to obtain a pellet. Supernatants were stored at $-80^{\circ} \mathrm{C}$ until needed.

\section{Clinical Samples}

The study was conducted in accordance with the guidelines of the ethical committees of the participating hospital, Centre Hospitalier Lyon Sud (Hospices civils de Lyon, Pierre Bénite, France) or Groupement Hospitalier Est (Hospices civils de Lyon, Bron, France) (DC-201-1306). Specimens from human $S$. aureus skin abscesses were collected as part of the routine management of patients and stored at $-80^{\circ} \mathrm{C}$ in Eppendorf tubes. A total of 23 samples were obtained and analyzed. For one patient, two samples were collected. For the $23 \mathrm{~S}$. aureus isolates, characterization by microarray (Table 1) and culture supernatant collection were carried out as described above.

\section{Mast Cell Activation/Degranulation and Lysis Assay}

HMC- 1 cells $\left(1 \times 10^{6}\right.$ cells $\left./ \mathrm{mL}\right)$ were incubated in Eppendorf tubes with PVL $(0.05,0.5$, or $5 \mu \mathrm{g} / \mathrm{mL}$, i.e., $0.0015,0.015,0.15$ $\mu \mathrm{M}$ respectively), Hla $(10 \mu \mathrm{g} / \mathrm{mL}$, i.e., $0.3 \mu \mathrm{M}), \mathrm{PSM} \alpha 1, \mathrm{PSM} \alpha 3$, Hld $(0.1,0.5,1,5,10,25,50,100$, or $200 \mu \mathrm{g} / \mathrm{mL}$, i.e., around 0.04 , $0.2,0.4,2,4,9,20,40$, or $80 \mu \mathrm{M}$ respectively), SF8300 wild-type (WT), SF8300 $\Delta p s m \alpha 1-3$, SF8300Hld(3G > T), or SF8300 $\Delta$ agrA supernatants $(20,10,5$, or $1 \% \mathrm{v} / \mathrm{v})$ for $3 \mathrm{~h}$ at $37^{\circ} \mathrm{C}$. Toxin concentrations were inferred from previous studies on human PMNs (Löffler et al., 2010) and preliminary results (data not published). The cells were pelleted by centrifugation at $200 \times \mathrm{g}$ for $10 \mathrm{~min}$ and the supernatants collected to measure tryptase by Immunocap (Phadia ${ }^{\circledR}$ ) assay and lactate dehydrogenase (LDH by Architect $\mathrm{c} 16000$ (Abbott $^{\circledR}$ ) assay. Mast cell degranulation and lysis were evaluated through tryptase release and $\mathrm{LDH}$ release, respectively, and expressed as percentages using the following formula: $\%=\frac{\text { Tryptase Test-Tryptase Tneg }}{\text { Tryptase Tpos-Tryptase Tneg }} \times 100$. The negative control (Tneg) was obtained using untriggered cell buffer and the positive control (Tpos) using cell lysis solution (Promega ${ }^{\circledR}$ ).

\section{PVL and Hla Quantification in Bacterial Supernatants}

The PVL level in the supernatant was quantified using a specific ELISA kindly provided by bioMérieux (R\&D Department, Marcy l'Étoile, France) as described elsewhere (Badiou et al., 2008). The concentration of Hla in the supernatant was quantified using a specific sandwich-type ELISA kindly provided by GlaxoSmithKline Vaccines that targets Hla with a solid-phase GlaxoSmithKline (GSK) monoclonal antibody, anti-Hla. The antibody-antigen complex was detected by a GSK polyclonal rabbit anti-Hla antibody followed by a peroxidase-conjugated goat anti-rabbit antibody as described previously (Otto et al., 2013).

\section{PSM Quantification in Bacterial Supernatants and Clinical Specimens}

Bacterial supernatants were thawed at $4^{\circ} \mathrm{C}$, diluted 1:5 with methanol at $4^{\circ} \mathrm{C}$, and incubated for $10 \mathrm{~min}$ at $4^{\circ} \mathrm{C}$. After centrifugation at $10,000 \times \mathrm{g}$ for $5 \mathrm{~min}$, the supernatants were recovered for PSM quantification. Clinical specimens were thawed to $4^{\circ} \mathrm{C}$, vortexed for $1 \mathrm{~min}$, sterilized by $1 \mathrm{~h}$ of heating at $94^{\circ} \mathrm{C}$, cooled on ice to $4^{\circ} \mathrm{C}$, diluted 1:5 with methanol at $4^{\circ} \mathrm{C}$, and incubated for $10 \mathrm{~min}$ at $4^{\circ} \mathrm{C}$. After centrifugation at $10,000 \times \mathrm{g}$ for $5 \mathrm{~min}$, the supernatants were recovered for PSM quantification. PSM $\alpha 1, \mathrm{PSM} \alpha 3$, and Hld were quantified by highperformance liquid chromatography mass spectrometry (HPLCMS) in an Agilent ${ }^{\circledR}$ system using an adaptation of a method described elsewhere (Wang et al., 2007).

\section{Statistical Analysis}

T-tests, ANOVA, Kruskal-Wallis tests following by Bonferroniadjusted Wilcox tests or $t$-tests, and a Pearson correlation test were performed to compare mast cell degranulation and mast cell lysis, as well as PSM and Hld production. $P \leq 0.05$ was considered significant.

\section{RESULTS}

\section{The Effect of Toxins on HMC-1 Cells}

Because in vitro and in vivo studies in animals have been implicated PSM $\alpha 1, \mathrm{PSM} \alpha 3$, Hld, Hla, and PVL in the pathophysiology of skin infections, we examined their effect on HMC- 1 cells by measuring the tryptase and $\mathrm{LDH}$ release. The range of concentrations used for each toxin was inferred from the literature (Badiou et al., 2008; Löffler et al., 2010). We observed that PSM $\alpha 1, \mathrm{PSM} \alpha 3$, and Hld induced tryptase and $\mathrm{LDH}$ release from HMC-1 cells in a dose-dependent manner (Kruskal-Wallis tests, $p<0.001$ for PSM $\alpha 1$, PSM $\alpha 3$, and Hld; Figures 1A-C). PSM $\alpha 1$ was more active than PSM $\alpha 3$ and Hld. The release of both $\mathrm{LDH}$ and tryptase was significantly higher with PSM $\alpha 1$ than with PSM $\alpha 3$ and Hld $(p<0.05)$, with the maximal release of tryptase and $\mathrm{LDH}$ in the presence of $200 \mu \mathrm{g} / \mathrm{mL}$ toxin (i.e., 88, 76 and $66 \mu \mathrm{M}$ for PSM $\alpha 1, \mathrm{PSM} \alpha 3$, and Hld respectively), achieving levels as high as $106.58 \pm 17.29$ and $89.99 \pm 4.89 \%$ of the positive control with PSM $\alpha 1,27.69 \pm 18.09$ and $39.41 \pm$ $6.74 \%$ with PSM $\alpha 3$, and $51.00 \pm 8.25$ and $28.66 \pm 4.08 \%$ with Hld. The lowest toxin concentration inducing tryptase and $\mathrm{LDH}$ release was $0.5 \mu \mathrm{g} / \mathrm{mL}$ for PSM $\alpha 1$ (i.e., $0.22 \mu \mathrm{M}$ ) and Hld (i.e., $0.16 \mu \mathrm{M}$ ) and $5 \mu \mathrm{g} / \mathrm{mL}$ for PSM $\alpha 3$ (i.e., $1.9 \mu \mathrm{M}$ ). Using PSM $\alpha 1$, PSM $\alpha 3$, and Hld, tryptase levels correlated with the LDH levels, suggesting that tryptase release was directly linked to mast cell lysis (Supplementary Figure 3).

In contrast to PSMs and Hld, PVL and Hla did not induce tryptase or LDH release by HMC-1 cells, even when applied at high concentrations $(5 \mu \mathrm{g} / \mathrm{mL}$, i.e., $0.15 \mu \mathrm{M})$ (Figure 1D). This negative data were not associated with the absence of activity in PVL and Hla preparations because they caused membrane 


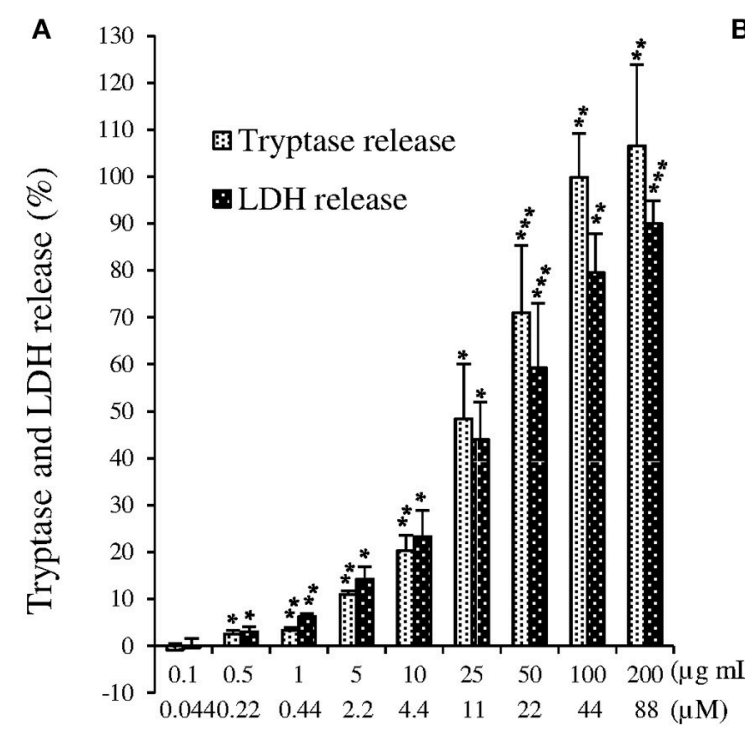

PSM $\alpha 1$ concentration

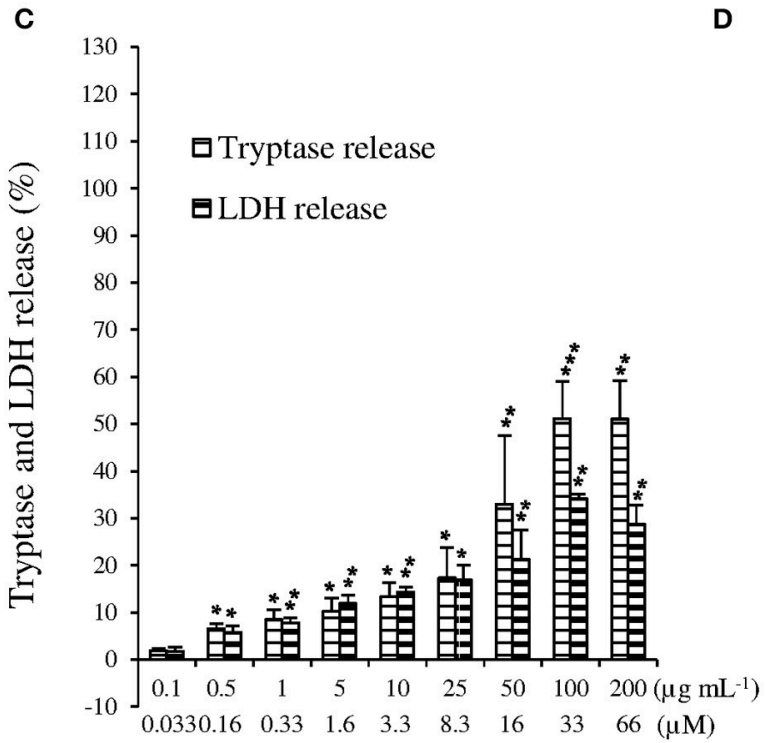

Hld concentration

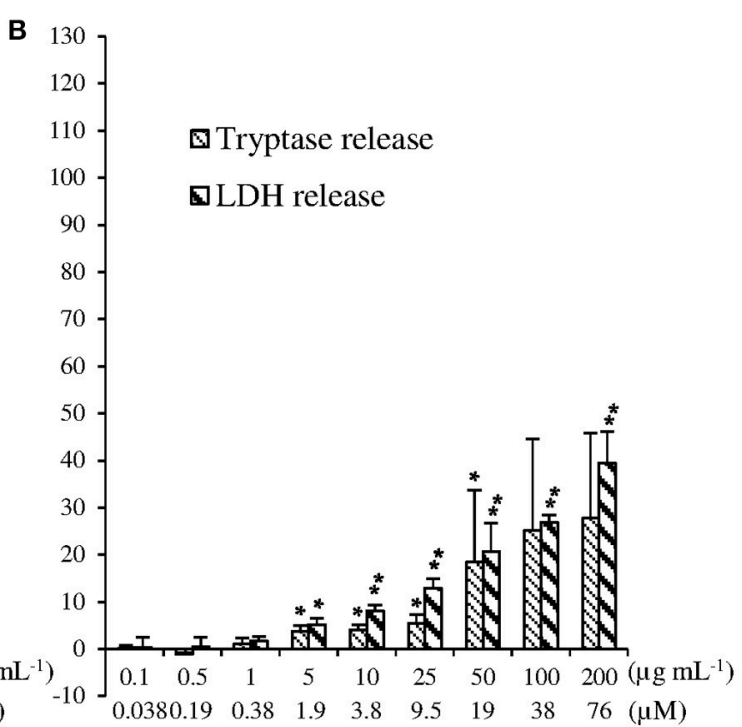

PSM $\alpha 3$ concentration

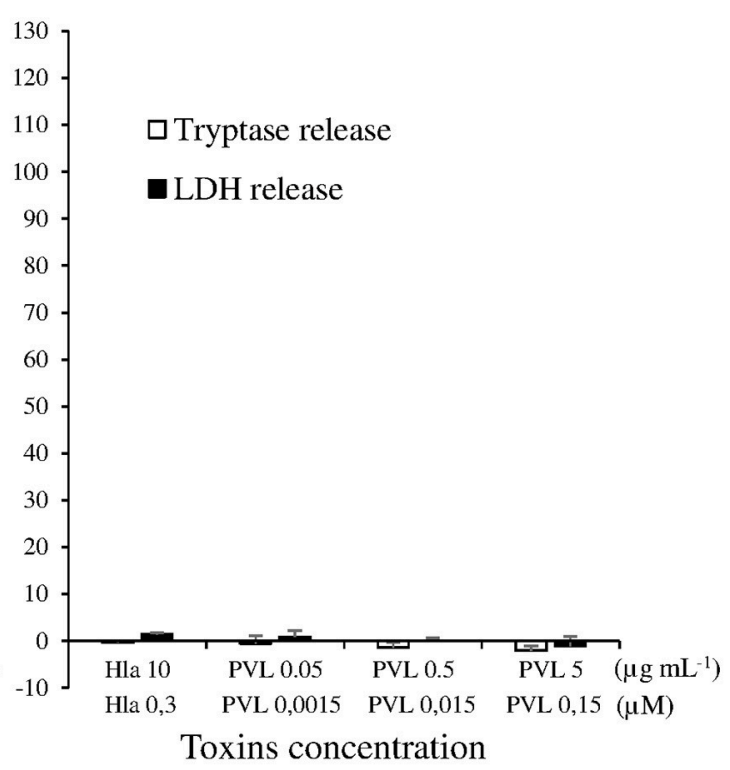

FIGURE 1 | (A) Effect of S. aureus PSM $\alpha$ 1, (B) PSM $\alpha 3$, (C) Hld, and (D) PVL and Hla on human mast cells. HMC-1 cells were incubated with increasing doses of PSM $\alpha 1$, PSM $\alpha 3$, HId (from $0.1 \mu \mathrm{g} / \mathrm{mL}$, i.e., around $4 \times 10^{-8} \mathrm{M}$ to $200 \mu \mathrm{g} / \mathrm{mL}$, i.e., around $8 \times 10^{-5} \mathrm{M}$ ), $\mathrm{PVL}$ (from $0.05 \mu \mathrm{g} / \mathrm{mL}$, i.e., $1.5 \times 10^{-9} \mathrm{M}$ to $5 \mu \mathrm{g} / \mathrm{mL}$, i.e., $\left.1.5 \times 10^{-7} \mathrm{M}\right)$, or $\mathrm{Hla}\left(3 \times 10^{-7} \mathrm{M}\right)$ for $3 \mathrm{~h}$ at $37^{\circ} \mathrm{C}$. Tryptase and LDH release were measured in cell supernatants by Immunocap $\left(\right.$ Phadia $\left.{ }^{\circledR}\right)$ and Architect $\left(\right.$ Abbot $\left.{ }^{\circledR}\right)$, respectively. The percentage of mast cell degranulation and mast cell lysis was calculated as $\frac{\text { Test-Tneg }}{\text { Tpos }- \text { Tneg }} \times 100$. The negative control and positive control were performed with cell buffer and lysis buffer, respectively. The values represent the mean $+S D$ of at least three independent experiments. To evaluate the dose-dependency on LDH and tryptase release, we performed Kruskal-Wallis tests for PSM 1 , PSM $\alpha 3$, and HId ( $p<0.001$ for the three toxins). To evaluate the lowest concentration inducing LDH or tryptase release that was significantly different from Tneg, $t$-tests of mean to 0 (Tneg) were performed for each toxin concentration. ${ }^{\star} p \leq 0.05,{ }^{\star \star} p \leq 0.01,{ }^{\star \star \star} p \leq 0.001$.

disruption of humans PMNs and rabbit erythrocytes, respectively (Supplementary Figures 1, 2).

\section{Effect Of S. aureus Supernatants on HMC-1 Cells}

We quantified Hla, PVL, PSM $\alpha 1$, PSM $\alpha 3$, and Hld in supernatants of SF8300 and its isogenic mutants to confirm their toxin production profiles. As expected, the concentrations of Hla and PVL in SF8300WT, SF8300Hld(3G > T), and SF8300 $\Delta$ psm $\alpha 1-4$ supernatants were similar (Hla: 0.4, 0.4, 0.4 $\mu \mathrm{g} / \mathrm{mL}$; PVL: $18,25,26 \mu \mathrm{g} / \mathrm{mL})$, whereas only a small amount of Hla and PVL was detected in SF8300 $\Delta$ agrA supernatant $(0.001$ and $0.2 \mu \mathrm{g} / \mathrm{mL}$, respectively). SF8300WT produced PSM $\alpha 1$ (4.07 $\pm 0.41 \mu \mathrm{g} / \mathrm{mL}), \mathrm{PSM} \alpha 3(3.00 \pm 0.10 \mu \mathrm{g} / \mathrm{mL})$, and Hld $(50.06$ 
$\pm 6.45 \mu \mathrm{g} / \mathrm{mL})$, whereas SF8300Hld(3G > T) produced only PSM $\alpha 1(6.30 \pm 0.64 \mu \mathrm{g} / \mathrm{mL})$ and PSM $\alpha 3(1.62 \pm 0.05 \mu \mathrm{g} / \mathrm{mL})$, SF8300 $\Delta$ psm $\alpha 1-4$ produced only Hld $(44.86 \pm 5.70 \mu \mathrm{g} / \mathrm{mL})$, and SF8300 $\Delta$ agrA produced none of the mediators (Figure 2 ).
When we examined the effect of the supernatant from the S. aureus SF3800 strain on HMC-1 cells, we observed that $\mathrm{LDH}$ and tryptase concentratons were consistent with the effect of synthetic peptides PSM $\alpha 1$, PSM $\alpha 3$, and Hld.
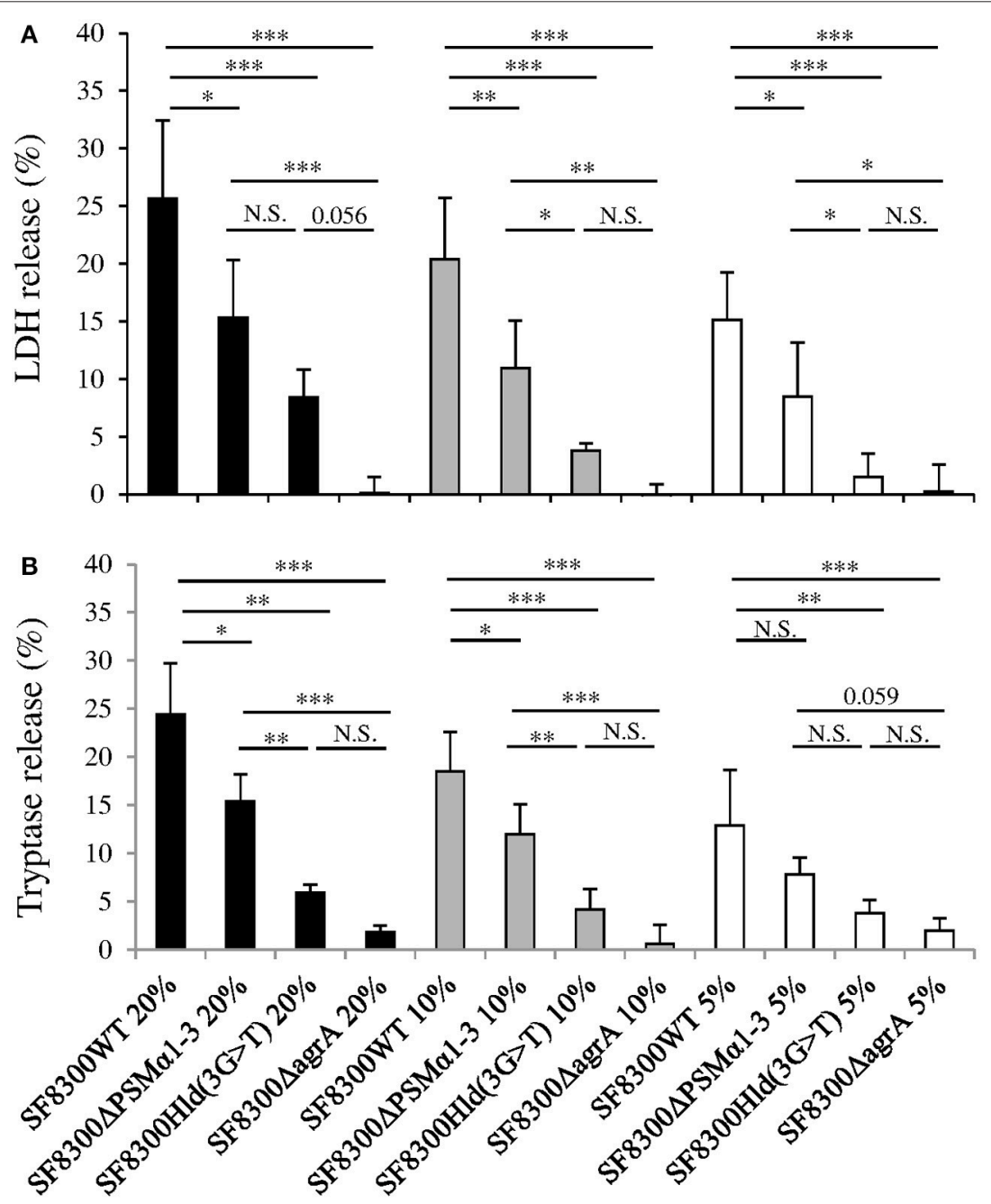

C

Hld and PSMal-3 concentrations in S. aureus strains supernatants

\begin{tabular}{|c|c|c|c|c|}
\hline & SF8300WT & SF8300 $\triangle P S M a 1-3$ & $\mathrm{SF} 8300 H l d(3 \mathrm{G}>\mathrm{T})$ & SF8300DagrA \\
\hline Hld $\left(\mu \mathrm{g} \mathrm{mL}^{-1}\right)$ & 50.06 & 44.86 & N.D. & N.D. \\
\hline PSM $\alpha 1 \quad\left(\mu g \mathrm{~mL}^{-1}\right)$ & 4.07 & N.D. & 6.30 & N.D. \\
\hline PSMa3 $(\mu \mathrm{g} \mathrm{mL}-1)$ & 3.00 & N.D. & 1.62 & N.D. \\
\hline
\end{tabular}

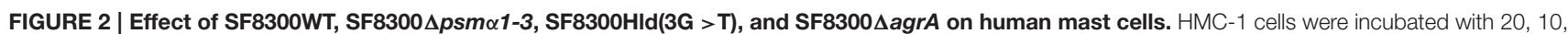
or $5 \%$ v/v S. aureus supernatants for $3 \mathrm{~h}$ at $37^{\circ} \mathrm{C}$. (A) LDH and (B) tryptase release was measured in cell supernatants by Architect (Abbot $\left.{ }^{\circledR}\right)$ and Immunocap $\left(\right.$ Phadia $\left.{ }^{\circledR}\right)$, respectively. The percentage of mast cell lysis and mast cell degranulation was calculated as $\frac{\text { Test-Tneg }}{\text { Tpos-Tneg }} \times 100$. The negative control and positive control were performed with medium and lysis buffer, respectively. The values represent the mean + SD of at least three independent experiments. (C) HId, PSM 1 , and PSM $\alpha 3$ concentrations in in each supernatant. To compare LDH and tryptase release by HMC-1 cells challenged with SF8300WT, SF8300 $\Delta$ psma $1-3$, SF8300HId(3G > T), or SF8300 $\Delta$ agrA supernatants, we performed $t$-test with Bonferroni correction followed by ANOVA. ${ }^{\star} p \leq 0.05,{ }^{\star \star} p \leq 0.01,{ }^{\star \star \star} p \leq 0.001$. N.S., not significant; N.D., not detected (toxin concentrations were less than the detection limit of $0.1 \mu \mathrm{g} / \mathrm{mL}$ ). 
LDH and tryptase release by HMC-1 cells was concentrationdependent (from 20 to 5\% v/v; ANOVA, $p<0.01$ ) and varied between SF3800WT and its isogenic mutants (Figure 2). The staphylococcal supernatant-induced levels of $\mathrm{LDH}$ and tryptase release (using 20 to $5 \% \mathrm{v} / \mathrm{v}$ ) in descending order were from SF8300WT, SF8300 $\Delta$ psma1-4, SF8300Hld(3G $>\mathrm{T}$ ), and SF8300 $\operatorname{agr}$. Taken together, these results indicate that $\mathrm{LDH}$ and tryptase release by HMC-1 cells challenged with $S$. aureus supernatants was mainly associated with Hld production and secondary to PSM $\alpha 1$ and PSM $\alpha 3$ production.

\section{PSM $\alpha$ and HId Quantification in Clinical Specimens}

As only PSM $\alpha 1, \mathrm{PSM} \alpha 3$, and Hld induced tryptase and $\mathrm{LDH}$ release by HMC-1 cells, we explored their production during human skin infection (Table 2). Hld was detected in 15 of the 23 pus samples at concentrations ranging from 0.1 to 19.6 $\mu \mathrm{g} / \mathrm{mL}$ (median $0.85 \mu \mathrm{g} / \mathrm{mL}$ ). PSM $\alpha 1$ was detected in only four of the pus samples at concentrations ranging from 0.1 to 3.9 $\mu \mathrm{g} / \mathrm{mL}$ (median $0.31 \mu \mathrm{g} / \mathrm{mL}$ ). Higher concentrations of Hld and PSM $\alpha 1$ were detected in the same pus samples. Twelve of the $15(80 \%)$ Hld-positive specimens reached toxic concentrations for HMC-1 cells (i.e., $0.5 \mu \mathrm{g} / \mathrm{mL}$ ), but only one pus sample contained a toxic concentration of PSM $\alpha 1$ for HMC-1 cells. Finally, PSM $\alpha 3$ was detected in none of the tested clinical specimens.

\section{In vitro PSM $\alpha$ and HId Production by s. aureus Strains}

Forty-six $S$. aureus clinical isolates from SSTIs were studied for PSM $\alpha 1, P S M \alpha 3$, and Hld production, including 23 from the clinical specimens analyzed for in vivo PSM and Hld production. The other 23 isolates were from the French staphylococci NRC collection with no pus available. Strains belonged to different agr groups and clonal complexes (Table 1): $45.6 \%$ (21/46) $S$. aureus strains in agr group 1, 19.6\% (9/46) in agr group 2, and $34.8 \%(16 / 46)$ in agr group 3. A majority (39/46) of strains were methicillin-susceptible $S$. aureus (MSSA), and five of seven methicillin-resistant $S$. aureus (MRSA) strains were luk- $P V$-positive. Four of the latter were community-acquired MRSA strains belonging to the European ST 80 clone, and one belonged to the ST8 USA300 clone. The remaining luk-PVpositive $S$. aureus strains $(n=11)$ were MSSA.

All S. aureus strains expressed PSM $\alpha 1, \mathrm{PSM} \alpha 3$, and Hld in vitro, though at different levels (Figure 3). Nevertheless, the mean Hld production $(94.51 \pm 52.02 \mu \mathrm{g} / \mathrm{mL})$ was much higher than the mean PSM $\alpha 1$ production $(8.10 \pm 7.91 \mu \mathrm{g} / \mathrm{mL})$,

TABLE 2 | HId, PSM $\alpha 1$, and PSM $\alpha 3$ concentrations in human skin abscesses and bacterial supernatants.

\begin{tabular}{|c|c|c|c|c|c|c|}
\hline \multirow[t]{2}{*}{ S. aureus isolate } & \multicolumn{3}{|c|}{ Pus ( $\mu \mathrm{g} \mathrm{mL}^{-1}$ ) } & \multicolumn{3}{|c|}{ Supernatant $\left(\mu \mathrm{g} \mathrm{mL}^{-1}\right)$} \\
\hline & HId & $\mathrm{PSM} \alpha 1$ & $\mathrm{PSM} \alpha 3$ & HId & $\mathrm{PSM} \alpha 1$ & $\mathrm{PSM} \alpha 3$ \\
\hline ST 20140441 & 19.57 & 3.92 & ND & $68.84 \pm 9.19$ & $14.45 \pm 4.28$ & $0.11 \pm 0.02$ \\
\hline ST 20120567 & 3.69 & ND & ND & $199.47 \pm 67.67$ & $33.73 \pm 8.48$ & $14.02 \pm 4.96$ \\
\hline ST 20141173 & 1.33 & ND & ND & $77.53 \pm 0.05$ & $5.76 \pm 2.11$ & $2.89 \pm 0.71$ \\
\hline ST 20130774 & 1.31 & ND & ND & $171.55 \pm 14.38$ & $12.16 \pm 2.70$ & $6.07 \pm 2.67$ \\
\hline ST 20151706 & 1.26 & 0.40 & ND & $88.49 \pm 12.44$ & $8.45 \pm 1.72$ & $2.94 \pm 0.82$ \\
\hline ST 20131442 & 1.13 & ND & ND & $141.12 \pm 13.58$ & $28.52 \pm 2.52$ & $17.10 \pm 7.06$ \\
\hline ST 20121497 & 0.90 & ND & ND & 128.72 & 8.91 & 2.07 \\
\hline ST 20151705 & 0.85 & ND & ND & $52.50 \pm 20.31$ & $1.12 \pm 0.89$ & $0.07 \pm 0.01$ \\
\hline 015033164401 & 0.82 & ND & ND & $98.75 \pm 0.69$ & $22.04 \pm 0.32$ & $0.08 \pm 0.01$ \\
\hline ST 20140409 & 0.67 & ND & ND & $37.79 \pm 4.29$ & $0.37 \pm 0.11$ & $0.06 \pm 0.03$ \\
\hline ST 20140351 & 0.59 & 0.22 & ND & $123.00 \pm 11.62$ & $10.42 \pm 0.71$ & $2.65 \pm 0.06$ \\
\hline ST 20151711 & 0.52 & ND & ND & $22.15 \pm 9.55$ & $0.33 \pm 0.08$ & $0.07 \pm 0.01$ \\
\hline ST 20141033 & 0.31 & 0.19 & ND & $43.56 \pm 2.02$ & $9.02 \pm 4.62$ & $2.58 \pm 1.58$ \\
\hline ST 20121322 & 0.26 & ND & ND & 71.81 & 1.61 & 0.42 \\
\hline ST 20140589 & 0.12 & ND & ND & $143.72 \pm 20.12$ & $10.95 \pm 2.94$ & $4.13 \pm 0.21$ \\
\hline ST 20141539 & ND & ND & ND & $143.53 \pm 25.19$ & $20.55 \pm 11.23$ & $6.70 \pm 3.86$ \\
\hline ST 20151708 & ND & ND & ND & $116.15 \pm 21.28$ & $7.95 \pm 2.25$ & $4.80 \pm 1.66$ \\
\hline ST 20141054 & ND & ND & ND & $92.21 \pm 4.28$ & $10.19 \pm 1.27$ & $2.92 \pm 0.46$ \\
\hline ST 20141524 & ND & ND & ND & $53.99 \pm 23.55$ & $2.20 \pm 1.53$ & $0.44 \pm 0.20$ \\
\hline ST 20151710 & ND & ND & ND & $33.09 \pm 2.19$ & $4.43 \pm 0.19$ & $0.08 \pm 0.01$ \\
\hline ST 20151707 & ND & ND & ND & $14.70 \pm 2.94$ & $0.47 \pm 0.17$ & $0.15 \pm 0.04$ \\
\hline ST 20141501 & ND & ND & ND & $7.66 \pm 4.91$ & $0.14 \pm 0.04$ & $0.07 \pm 0.03$ \\
\hline ST 20151709 & ND & ND & ND & $4.38 \pm 3.05$ & $<0.1$ & $0.07 \pm 0.03$ \\
\hline
\end{tabular}

ND, not detected. 
which was higher than the mean PSM $\alpha 3$ production (3.09 $\pm 3.79 \mu \mathrm{g} / \mathrm{mL}$ ) (Figure 3A). The in vitro production levels of the three toxins were not different between MRSA and MSSA (Figures 3B-D). We did not notice any difference in the in vitro PSM $\alpha 1$ and PSM $\alpha 3$ production levels between luk- $P V$-positive $(n=16)$ and luk-PV-negative $(n=30)$ $S$. aureus strains (Figures 3C,D). However, luk- $P V$-positive strains produced more Hld $(113.05 \pm 46.42 \mu \mathrm{g} / \mathrm{mL})$ than $l u k$ $P V$-negative strains $(84.62 \pm 52.86 \mu \mathrm{g} / \mathrm{mL}, p<0.05$; Figure 3B). We also observed that $S$. aureus from agr group 1 produced higher levels of Hld, PSM $\alpha 1$, and PSM $\alpha 3$ than S. aureus from agr groups 2 and 3 ( $p<0.05$; Figures 3B-D). No significant difference was found in PSM $\alpha 1, \mathrm{PSM} \alpha 3$, and Hld production between community-acquired MRSA and the other $S$. aureus strains.

Regarding the 23 S. aureus strains isolated from pus, we found higher toxin concentrations in culture supernatants than clinical specimens (Table 2). In vitro toxin production ranged from 4.38 to $199.47 \mu \mathrm{g} / \mathrm{mL}$ (median $77.53 \mu \mathrm{g} / \mathrm{mL}$ ) for Hld, from $<0.1$ to $33.73 \mu \mathrm{g} / \mathrm{mL}$ (median $8.2 \mu \mathrm{g} / \mathrm{mL}$ ) for PSM $\alpha 1$, and from 0.06 to
$17.1 \mu \mathrm{g} / \mathrm{mL}$ (median $2.07 \mu \mathrm{g} / \mathrm{mL}$ ) for PSM $\alpha 3$. No correlation was observed between in vivo and in vitro Hld quantification (Supplementary Figure 4).

\section{DISCUSSION}

Despite progress in our knowledge of $S$. aureus pathophysiology, virulence factors that favor its transmission remain enigmatic. Hands play a significant role in the spread of S. aureus to new hosts through contact with skin colonized or infected by $S$. aureus. In the skin, dermal mast cells act in close interaction with nerve fibers and contain substances that act as mediators of itching (Ständer et al., 2008). In this study, we examined whether $S$. aureus pore-forming toxins that are involved in the pathophysiology of skin infection can induce mast cell activation/lysis. We used HMC-1 cells derived from a patient with leukemia. Even though this cell line has two major deficiencies (cytokine-independence and lack of a functional FceR), it is widely used and a faithful in vitro model of normal

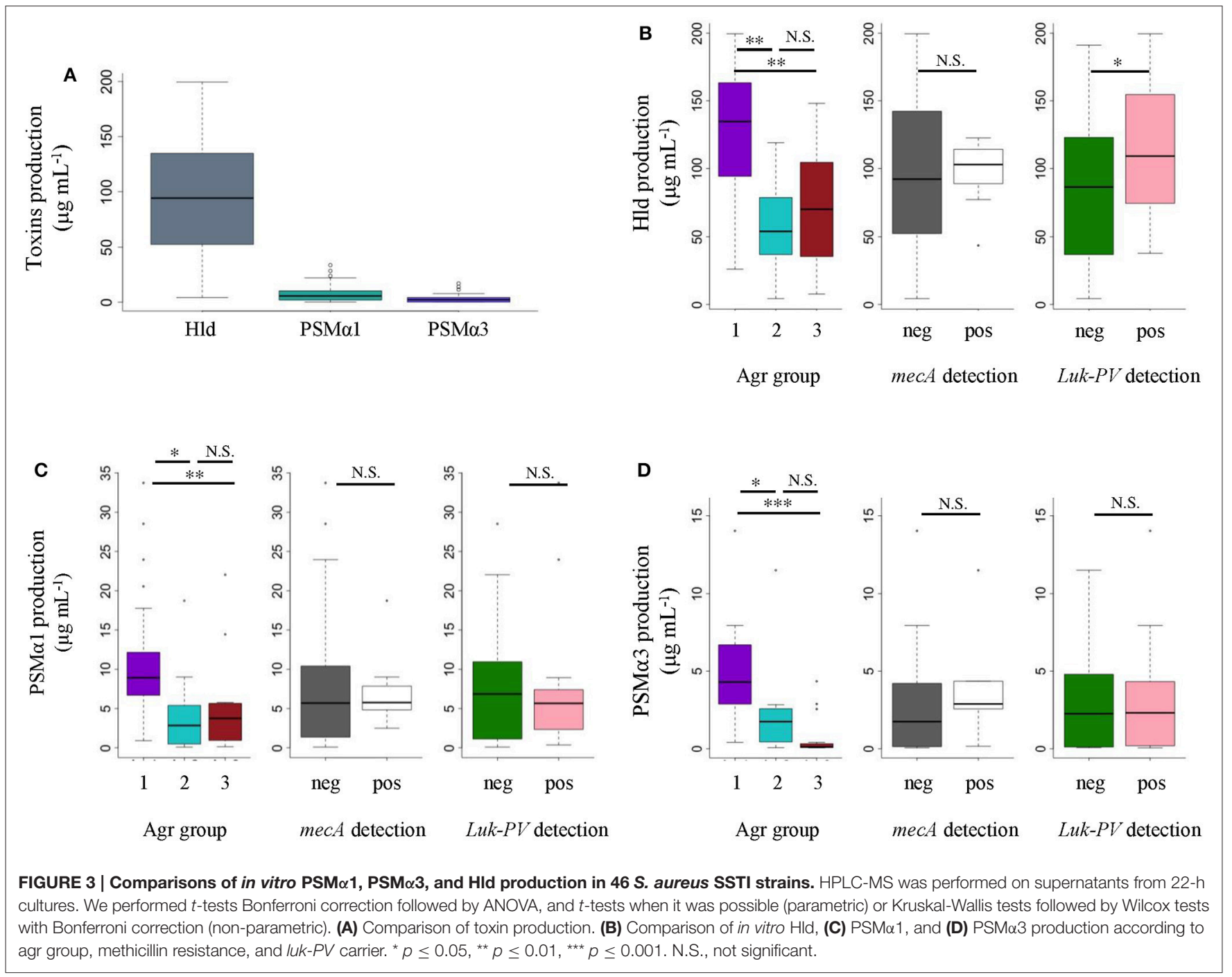


mast cells (Drexler and MacLeod, 2003). We verified that HMC1 cells produce tryptase, one of the best indicators of mast cell activation (Schwartz et al., 2003; Guhl et al., 2010), and express CD88 similar to human skin mast cells (Füreder et al., 1995; Werfel et al., 1996) (Supplementary Figure 5).

Our results clearly demonstrate that PSM $\alpha 1, \mathrm{PSM} \alpha 3$, and Hld induce dose-dependent tryptase and LDH release by HMC-1 cells. We suspect that tryptase liberation was mainly the result of mast cell lysis. In contrast, PVL and Hla did not induce human HMC-1 cell degranulation or lysis. This finding was unexpected because König et al. (1995) reported that PVL induces histamine release by human basophilic granulocytes, immune cells that are morphologically and functionally related to mast cells, especially given that the HMC-1 cell line expresses C5aR, the PVL receptor (König et al., 1995; Spaan et al., 2013). Two major hypotheses are possible to explain this discrepancy. Either HMC-1 cells do not express enough CD88 to make the cell sensitive to PVL and/or there is an additional specific co-receptor necessary for PVL to be active that is missing from HMC-1 cells. Supplementary investigations should be performed to test these hypotheses.

We found a similar cytotoxic effect of PSM $\alpha 1$ and PSM $\alpha 3$ on HMC-1 cells as those previously reported with human neutrophils. The lethal concentration $50 \%$ was achieved in both mast cells and human neutrophils at $25 \mu \mathrm{g} / \mathrm{mL}$ PSM $\alpha 1$ (Löffler et al., 2010). However, for PSM $\alpha 3$, we observed only $20 \%$ lysis of mast cells at the concentration that results in the $80 \%$ lysis of neutrophils (i.e., $50 \mu \mathrm{g} / \mathrm{mL}$ ) (Löffler et al., 2010). We observed the same level of Hld activity against mast cells as Nakamura et al.; using $10 \mu \mathrm{g} / \mathrm{mL}$ we measured $13.30 \pm 3.01 \%$ tryptase release, whereas they reported $\beta$-hexosaminidase release of $\sim 10 \%$ (Nakamura et al., 2013). The only difference was that $\beta$ hexosaminidase release by Hld seems to not be related to cell lysis of the mouse MC/9 mast cell line, which is in contrast to what we observed with HMC-1 cells. This may be due to the different origins of the mast cell lines.

In order to determine whether PSM $\alpha 1, \mathrm{PSM} \alpha 3$, and Hld are expressed in vivo, 23 pus samples recovered from human $S$. aureus skin abscesses were analyzed. We detected the presence of Hld in $65 \%$ of the analyzed clinical specimens and PSM $\alpha 1$ in $17 \%$ of the samples, but no PSM $\alpha 3$. The concentration of Hld and PSM $\alpha 1$ detected in pus samples was 50- and 10-fold lower, respectively, than the concentrations produced in vitro and did not correlate. The weakest toxin concentration in vivo may indicate that the toxins were degraded more rapidly in pus than in supernatants, despite similar storage procedures. Only $50 \%$ of pus samples contained sufficient Hld levels to induce HMC-1 cell lysis, but it was $100 \%$ with the in vitro supernatants. In vitro Hld production was 10-fold higher than mean PSM $\alpha 1$ production and 30 -fold higher than PSM $\alpha 3$ production as described previously (Berlon et al., 2015).

Two studies recently demonstrated that PSM and Hld production by MRSA and MSSA is higher among SSTI isolates than either infectious endocarditis or hospital-acquired pneumonia (Berlon et al., 2015; Qi et al., 2016). These observations suggested that the level of PSM and Hld correlates more with the disease than the methicillin-resistant status. As PSM and Hld production is regulated by the agr, the level of PSM and Hld production may reflect agr activity and its requirement for the development of skin infection in humans, as in animal models of S. aureus skin infection (Montgomery et al., 2010; Cheung et al., 2011). Looking at the impact of agr alleles in our sample, strains in agr group 1 produced more Hld, PSM $\alpha 1$, and PSM $\alpha 3$ than those from groups 2 and 3, despite CA-MRSA belonging mainly to agr group 3 (Tristan et al., 2007).

The involvement of PSM $\alpha 1-3$ in SSTI pathogenesis was demonstrated by Wang et al., who showed that $S$. aureus strains producing PSM $\alpha$ are more virulent, notably through the capacity of PSM $\alpha$ to lyse neutrophils (Wang et al., 2007). Recently, Syed et al. highlighted the involvement of $S$. aureus $\mathrm{PSM} \alpha$, including Hld, in the induction of skin inflammation through pro-inflammatory cytokine release from keratinocytes (Syed et al., 2015). Skin mast cells are very important immune cells and participate in the fight against pathogens, but they can be deleterious when over-stimulated (Abraham and St. John, 2010; Urb and Sheppard, 2012; St. John and Abraham, 2013). This deleterious effect has been shown in mice, with Hld participating in the development of atopic dermatitis (Nakamura et al., 2013). Therefore, our results suggest that S. aureus produces Hld during acute skin infection, and to a lesser extent PSM $\alpha 1$, which induces mast cell degranulation and/or lysis directly or indirectly through skin inflammation. This human skin mast cell degranulation activates neuroreceptors on sensory nerve fibers involved in the induction of pruritus and explain the itchy feeling during $S$. aureus skin infections (Zhu et al., 2015). We speculate that the scratching behavior induced by $S$. aureus though Hld and PSM production promotes $S$. aureus transmission via hand-to-skin contact in the presence of $S$. aureus-infected skin lesions, thereby promoting $S$. aureus epidemicity. As highlighted previously, agr is a key regulatory system for the maintenance of $S$. aureus virulence, which is considered a key factor for host-to-host transmission (Massey et al., 2006). Moreover, Hld is encoded by RNAIII, the effector of agr (Novick et al., 1993). We hypothesize that the Hld-agr association contributes to the elective transmission of virulent $S$. aureus strains with a functional agr system. Altogether could participate in the epidemic success of certain S. aureus strains, such as the pandemic CA-MRSA USA300 clone that strongly expresses toxins with the help of the agr system, induces itchy skin infections, and is pandemic in the USA (DeLeo et al., 2010; Cheung et al., 2011; Suchard, 2011).

In conclusion, our results demonstrate that Hld and PSM $\alpha 1$ are produced by $S$. aureus in vivo and induce human mast cell degranulation and lysis. As mast cell mediators are known to be involved in the induction of pruritus, we hypothesize that $S$. aureus may promote its transmission via the hands through scratching of infected skin lesions prompted by Hld and PSM production.

\section{ETHICS STATEMENT}

This study was conducted according to the principles of the Declaration of Helsinki and its subsequent amendments, the guidelines for Good Clinical Practices (CPMP/ICH/135/95), the 
French regulations and the guidelines of the ethical committees of the participating hospital, Centre Hospitalier Lyon Sud (Hospices civils de Lyon, Pierre Benite, France), and Groupement Hospitalier Est (Hospices civils de Lyon, Bron, France) (DC201-1306). Only specimens from human $S$. aureus skin abscesses were collected as part of the routine management of patients was examined.

\section{AUTHOR CONTRIBUTIONS}

$\mathrm{EH}, \mathrm{VL}, \mathrm{BD}, \mathrm{MB}, \mathrm{AT}, \mathrm{GL}$, and OD designed the experiments. $\mathrm{EH}$, $\mathrm{CC}, \mathrm{CB}, \mathrm{FB}, \mathrm{JS}, \mathrm{RC}$, and AP performed the experiments. $\mathrm{EH}, \mathrm{VL}$, $\mathrm{BD}, \mathrm{GL}$, and OD wrote the manuscript.

\section{REFERENCES}

Abel, J., Goldmann, O., Ziegler, C., Höltje, C., Smeltzer, M. S., Cheung, A. L., et al. (2011). Staphylococcus aureus evades the extracellular antimicrobial activity of mast cells by promoting its own uptake. J. Innate Immun. 3, 495-507. doi: $10.1159 / 000327714$

Abraham, S. N., and St. John, A. L. (2010). Mast cell-orchestrated immunity to pathogens. Nat. Rev. Immunol. 10, 440-452. doi: 10.1038/nri2782

Badiou, C., Dumitrescu, O., Croze, M., Gillet, Y., Dohin, B., Slayman, D. H., et al. (2008). Panton-Valentine leukocidin is expressed at toxic levels in human skin abscesses. Clin. Microbiol. Infect. 14, 1180-1183. doi: 10.1111/j.1469-0691.2008.02105.x

Bae, T., and Schneewind, O. (2006). Allelic replacement in Staphylococcus aureus with inducible counter-selection. Plasmid 55, 58-63. doi: 10.1016/j.plasmid.2005.05.005

Berlon, N. R., Qi, R., Sharma-Kuinkel, B. K., Joo, H. S., Park, L. P., George, D., et al. (2015). Clinical MRSA isolates from skin and soft tissue infections show increased in vitro production of phenol soluble modulins. J. Infect. 71, 447-457. doi: 10.1016/j.jinf.2015.06.005

Bloomfield, S. F., and Scott, E. (1997). Cross-contamination and infection in the domestic environment and the role of chemical disinfectants. J. Appl. Microbiol. 83, 1-9. doi: 10.1046/j.1365-2672.1997.00199.x

Cameron, E. A., and Sperandio, V. (2015). Frenemies: signaling and nutritional integration in pathogen-microbiota-host interactions. Cell Host Microbe 18, 275-284. doi: 10.1016/j.chom.2015.08.007

Cézilly, F., and Perrot-Minnot, M. J. (2005). Studying adaptive changes in the behaviour of infected hosts: a long and winding road. Behav. Processes 68, 223-228. doi: 10.1016/j.beproc.2004.08.013

Cheung, G. Y., Wang, R., Khan, B. A., Sturdevant, D. E., and Otto, M. (2011). Role of the accessory gene regulator agr in community-associated methicillinresistant Staphylococcus aureus pathogenesis. Infect. Immun. 79, 1927-1935. doi: 10.1128/IAI.00046-11

DeLeo, F. R., Otto, M., Kreiswirth, B. N., and Chambers, H. F. (2010). Communityassociated meticillin-resistant Staphylococcus aureus. Lancet 375, 1557-1568. doi: 10.1016/S0140-6736(09)61999-1

Diep, B. A., Chan, L., Tattevin, P., Kajikawa, O., Martin, T. R., Basuino, L., et al. (2010). Polymorphonuclear leukocytes mediate Staphylococcus aureus PantonValentine leukocidin-induced lung inflammation and injury. Proc. Natl. Acad. Sci. U.S.A. 107, 5587-5592. doi: 10.1073/pnas.0912403107

Di Nardo, A., Vitiello, A., and Gallo, R. L. (2003). Cutting edge: mast cell antimicrobial activity is mediated by expression of cathelicidin antimicrobial peptide. J. Immunol. 170, 2274-2278. doi: 10.4049/jimmunol.170.5. 2274

Drexler, H. G., and MacLeod, R. A. (2003). Malignant hematopoietic cell lines: in vitro models for the study of mast cell leukemia. Leuk. Res. 27, 671-676. doi: 10.1016/S0145-2126(03)00007-9

Dumitrescu, O., Choudhury, P., Boisset, S., Badiou, C., Bes, M., Benito, Y., et al. (2011). Beta-lactams interfering with PBP1 induce PantonValentine leukocidin expression by triggering sarA and rot global regulators

\section{FUNDING}

This work was supported in part by the LABEX ECOFECT (ANR-11-LABX-0048) of Université de Lyon, within the program "Investissements d'Avenir" (ANR-11-IDEX0007) operated by the French National Research Agency (ANR).

\section{SUPPLEMENTARY MATERIAL}

The Supplementary Material for this article can be found online at: http://journal.frontiersin.org/article/10.3389/fcimb. 2016.00180/full\#supplementary-material

of Staphylococcus aureus. Antimicrob. Agents Chemother. 55, 3261-3271. doi: 10.1128/AAC.01401-10

Feng, B. S., He, S. H., Zheng, P. Y., Wu, L., and Yang, P. C. (2007). Mast cells play a crucial role in Staphylococcus aureus peptidoglycan-induced diarrhea. Am. J. Pathol. 171, 537-547. doi: 10.2353/ajpath.2007.061274

Füreder, W., Agis, H., Willheim, M., Bankl, H. C., Maier, U., Kishi, K., et al. (1995). Differential expression of complement receptors on human basophils and mast cells. Evidence for mast cell heterogeneity and CD88/C5aR expression on skin mast cells. J. Immunol. 155, 3152-3160.

Galli, S. J., Borregaard, N., and Wynn, T. A. (2011). Phenotypic and functional plasticity of cells of innate immunity: macrophages, mast cells and neutrophils. Nat. Immunol. 12, 1035-1044. doi: 10.1038/ni.2109

Goldmann, O., Tuchscherr, L., Rohde, M., and Medina, E. (2016). $\alpha$-Hemolysin enhances Staphylococcus aureus internalization and survival within mast cells by modulating the expression of $\beta 1$ integrin. Cell Microbiol. 18, 807-819. doi: $10.1111 / \mathrm{cmi} .12550$

Guhl, S., Babina, M., Neou, A., Zuberbier, T., and Artuc, M. (2010). Mast cell lines HMC-1 and LAD2 in comparison with mature human skin mast cellsdrastically reduced levels of tryptase and chymase in mast cell lines. Exp. Dermatol. 19, 845-847. doi: 10.1111/j.1600-0625.2010.01103.x

Johnzon, C. F., Rönnberg, E., Guss, B., and Pejler, G. (2016). Live Staphylococcus aureus induces expression and release of vascular endothelial growth factor in terminally differentiated mouse mast cells. Front. Immunol. 7:247. doi: 10.3389/fimmu.2016.00247

Kobayashi, S. D., Malachowa, N., Whitney, A. R., Braughton, K. R., Gardner, D. J., Long, D., et al. (2011). Comparative analysis of USA300 virulence determinants in a rabbit model of skin and soft tissue infection. J. Infect. Dis. 204, 937-941. doi: 10.1093/infdis/jir441

Kong, C., Neoh, H. M., and Nathan, S. (2016). Targeting Staphylococcus aureus Toxins: a potential form of anti-virulence therapy. Toxins 8:E72. doi: $10.3390 /$ toxins 8030072

König, B., Prévost, G., Piémont, Y., and König, W. (1995). Effects of Staphylococcus aureus leukocidins on inflammatory mediator release from human granulocytes. J. Infect. Dis. 171, 607-613. doi: 10.1093/infdis/171.3.607

Kupper, T. S., and Fuhlbrigge, R. C. (2014). Immune surveillance in the skin: mechanisms and clinical consequence. Nat. Rev. Immunol. 4, 211-222. doi: $10.1038 /$ nri1310

Lina, G., Jarraud, S., Ji, G., Greenland, T., Pedraza, A., Etienne, J., et al. (1998). Transmembrane topology and histidine protein kinase activity of AgrC, the agr signal receptor in Staphylococcus aureus. Mol. Microbiol. 28, 655-662. doi: 10.1046/j.1365-2958.1998.00830.x

Lipinska, U., Hermans, K., Meulemans, L., Dumitrescu, O., Badiou, C., Duchateau, L., et al. (2011). Panton-Valentine leukocidin does play a role in the early stage of Staphylococcus aureus skin infections: a rabbit model. PLoS ONE 6:e22864. doi: 10.1371/journal.pone.0022864

Löffler, B., Hussain, M., Grundmeier, M., Brück, M., Holzinger, D., Varga, G., et al. (2010). Staphylococcus aureus panton-valentine leukocidin is a very potent cytotoxic factor for human neutrophils. PLoS Pathog. 6:e1000715. doi: 10.1371/journal.ppat.1000715 
Lowy, F. D. (1998). Staphylococcus aureus infections. N. Engl. J. Med. 339, 520-532. doi: 10.1056/NEJM199808203390806

Massey, R. C., Horsburgh, M. J., Lina, G., Höök, M., and Recker, M. (2006). The evolution and maintenance of virulence in Staphylococcus aureus: a role for host-to-host transmission? Nat. Rev. Microbiol. 4, 953-958. doi: 10.1038/nrmicro1551

Monecke, S., Luedicke, C., Slickers, P., and Ehricht, R. (2009). Molecular epidemiology of Staphylococcus aureus in asymptomatic carriers. Eur. J. Clin. Microbiol. Infect. Dis. 28, 1159-1165. doi: 10.1007/s10096-009$0752-2$

Montgomery, C. P., Boyle-Vavra, S., and Daum, R. S. (2010). Importance of the global regulators Agr and SaeRS in the pathogenesis of CA-MRSA USA300 infection. PLoS ONE 5:e15177. doi: 10.1371/journal.pone.0015177

Nakamura, Y., Oscherwitz, J., Cease, K. B., Chan, S. M., Muñoz-Planillo, R., Hasegawa, M., et al. (2013). Staphylococcus $\delta$-toxin induces allergic skin disease by activating mast cells. Nature 503, 397-401. doi: 10.1038/nature12655

Novick, R. P., Ross, H. F., Projan, S. J., Kornblum, J., Kreiswirth, B., and Moghazeh, S. (1993). Synthesis of staphylococcal virulence factors is controlled by a regulatory RNA molecule. EMBO J. 12, 3967-3975.

Otto, M. P., Martin, E., Badiou, C., Lebrun, S., Bes, M., Vandenesch, F., et al. (2013). Effects of subinhibitory concentrations of antibiotics on virulence factor expression by community-acquired methicillin-resistant Staphylococcus aureus. J. Antimicrob. Chemother. 68, 1524-1532. doi: 10.1093/jac/dkt073

Perret, M., Badiou, C., Lina, G., Burbaud, S., Benito, Y., Bes, M., et al. (2012). Cross-talk between Staphylococcus aureus leukocidins-intoxicated macrophages and lung epithelial cells triggers chemokine secretion in an inflammasome-dependent manner. Cell Microbiol. 14, 1019-1036. doi: 10.1111/j.1462-5822.2012.01772.x

Peschel, A., and Otto, M. (2013). Phenol-soluble modulins and staphylococcal infection. Nat. Rev. Microbiol. 11, 667-673. doi: 10.1038/nrmicro3110

Pozzi, C., Lofano, G., Mancini, F., Soldaini, E., Speziale, P., De Gregorio, E., et al. (2015). Phagocyte subsets and lymphocyte clonal deletion behind ineffective immune response to Staphylococcus aureus. FEMS Microbiol. Rev. 39, 750-763. doi: 10.1093/femsre/fuv024

Qi, R., Joo, H. S., Sharma-Kuinkel, B., Berlon, N. R., Park, L., Fu, C. L., et al. (2016). Increased in vitro phenol-soluble modulin production is associated with soft tissue infection source in clinical isolates of methicillin-susceptible Staphylococcus aureus. J. Infect. 72, 302-308. doi: 10.1016/j.jinf.2015.11.002

Queck, S. Y., Jameson-Lee, M., Villaruz, A. E., Bach, T. H., Khan, B. A., Sturdevant, D. E., et al. (2008). RNAIII-independent target gene control by the agr quorum-sensing system: insight into the evolution of virulence regulation in Staphylococcus aureus. Mol. Cell 32, 150-158. doi: 10.1016/j.molcel.2008.08.005

Rönnberg, E., Johnzon, C. F., Calounova, G., Garcia Faroldi, G., Grujic, M., Hartmann, K., et al. (2014). Mast cells are activated by Staphylococcus aureus in vitro but do not influence the outcome of intraperitoneal S. aureus infection in vivo. Immunology 143, 155-163. doi: 10.1111/imm.12297

Schwartz, L. B., Min, H. K., Ren, S., Xia, H. Z., Hu, J., Zhao, W., et al. (2003). Tryptase precursors are preferentially and spontaneously released, whereas mature tryptase is retained by HMC-1 cells, Mono-Mac6 cells, and human skin-derived mast cells. J. Immunol. 170, 5667-5673. doi: $10.4049 /$ jimmunol.170.11.5667

Shropshire, J. D., and Bordenstein, S. R. (2016). Speciation by symbiosis: the microbiome and behavior. MBio 7:e01785. doi: 10.1128/mBio.01785-15

Spaan, A. N., Henry, T., van Rooijen, W. J., Perret, M., Badiou, C., Aerts, P. C., et al. (2013). The staphylococcal toxin Panton-Valentine Leukocidin targets human C5a receptors. Cell Host Microbe 13, 584-594. doi: 10.1016/j.chom.2013. 04.006

Ständer, S., Weisshaar, E., and Luger, T. A. (2008). Neurophysiological and neurochemical basis of modern pruritus treatment. Exp. Dermatol. 17, 161-169. doi: 10.1111/j.1600-0625.2007.00664.x

St. John, A. L., and Abraham, S. N. (2013). Innate immunity and its regulation by mast cells. J. Immunol. 190, 4458-4463. doi: 10.4049/jimmunol.1203420

Suchard, J. R. (2011). "Spider bite" lesions are usually diagnosed as skin and soft-tissue infections. J. Emerg. Med. 41, 473-481. doi: 10.1016/j.jemermed.2009.09.014

Swindle, E. J., Brown, J. M., Rådinger, M., DeLeo, F. R., and Metcalfe, D. D. (2015). IFN- $\gamma$ enhances both the anti-bacterial and the pro-inflammatory response of human mast cells to $S$. aureus. Immunology 146, 470-485. doi: $10.1111 /$ imm. 12524

Syed, A. K., Reed, T. J., Clark, K. L., Boles, B. R., and Kahlenberg, J. M. (2015). Staphylococcus aureus phenol soluble modulins stimulate the release of proinflammatory cytokines from keratinocytes and are required for induction of skin inflammation. Infect. Immun. 83, 3428-3437. doi: 10.1128/IAI.00401-15

Tristan, A., Bes, M., Meugnier, H., Lina, G., Bozdogan, B., Courvalin, P., et al. (2007). Global distribution of Panton-Valentine leukocidin-positive methicillin-resistant Staphylococcus aureus, 2006. Emerg. Infect. Dis. 13, 594-600. doi: 10.3201/eid1304.061316

Urb, M., and Sheppard, D. C. (2012). The role of mast cells in the defence against pathogens. PLoS Pathog. 8:e1002619. doi: 10.1371/journal.ppat.1002619

Vandenesch, F., Kornblum, J., and Novick, R. P. (1991). A temporal signal, independent of agr, is required for hla but not spa transcription in Staphylococcus aureus. J. Bacteriol. 173, 6313-6320. doi: 10.1128/jb.173.20.6313-6320.1991

Wagner, J. E., Owens, D. R., LaRegina, M. C., and Vogler, G. A. (1997). Self trauma and Staphylococcus aureus in ulcerative dermatitis of rats. J. Am. Vet. Med. Assoc. 171, 839-841.

Wang, R., Braughton, K. R., Kretschmer, D., Bach, T. H., Queck, S. Y., Li, M., et al. (2007). Identification of novel cytolytic peptides as key virulence determinants for community-associated MRSA. Nat. Med. 13, 1510-1514. doi: $10.1038 / \mathrm{nm} 1656$

Werfel, T., Oppermann, M., Butterfield, J. H., Begemann, G., Elsner, J., Götze, O., et al. (1996). The human mast cell line HMC-1 expresses C5a receptors and responds to C5a but not to C5a(desArg). Scand. J. Immunol. 44, 30-36. doi: 10.1046/j.1365-3083.1996.d01-272.x

Zhu, Y., Pan, W. H., Wang, X. R., Liu, Y., Chen, M., Xu, X. G., et al. (2015). Tryptase and protease-activated receptor-2 stimulate scratching behavior in a murine model of ovalbumin-induced atopic-like dermatitis. Int. Immunopharmacol. 28, 507-512. doi: 10.1016/j.intimp.2015.04.047

Conflict of Interest Statement: The authors declare that the research was conducted in the absence of any commercial or financial relationships that could be construed as a potential conflict of interest.

Copyright (๑) 2016 Hodille, Cuerq, Badiou, Bienvenu, Steghens, Cartier, Bes, Tristan, Plesa, Le, Diep, Lina and Dumitrescu. This is an open-access article distributed under the terms of the Creative Commons Attribution License (CC BY). The use, distribution or reproduction in other forums is permitted, provided the original author(s) or licensor are credited and that the original publication in this journal is cited, in accordance with accepted academic practice. No use, distribution or reproduction is permitted which does not comply with these terms. 